\title{
Unpacking Refugee Flight: Critical Content Analysis of Picturebooks Featuring Refugee Protagonists
}

\author{
Ekaterina Strekalova-Hughes \\ University of Missouri-Kansas City \\ U. S. A.
}

\begin{abstract}
In this paper, I analyze representations of refugee flight in children's literature to extrapolate related assumptions about power and agency. The findings suggest that picturebooks tend to adhere to refugee flight as a bureaucratic process and refugee as an institutionally imposed standardized identity. Specifically, stories canonically mirror the legal UNHCR definition of a refugee, establishing forced-to-flee narratives, centering persecution, and corroborating well-founded fear. Collectively, stories mask what leads to persecution and distribute power to essentialized "safe" countries resettling refugees. The implications call for diversity of representation and invite teachers to critically unpack contexts of refugee flight.
\end{abstract}

KEYWORDS: children's literature, power and agency, refugee flight, refugee label, RefugeeCrit

\author{
Theoretical Framework \\ Literature Review \\ Methodology \\ Findings and Discussion \\ Conclusions \\ Implications \\ References \\ Appendix \\ Author Contact
}

At times of increasingly politicized refugee crises (United Nations High Commissioner for Refugees (UNHCR), 2018a), half of the world's refugees are children of school age (UNHCR, 2018b). Influenced by these events, teachers may wish to include texts affirming identities of students from refugee backgrounds in their classrooms. Good intentions, however, may not be enough to dismantle prevailing inequities in global power and privilege distribution (Gorski, 2008). Designed to influence beliefs and invoke emotion (Stephens, 1992), children's literature absorbs and reproduces discourses that might benefit from critical literacy discussions (Vasquez, 2017). 
As a more recent genre, stories centering refugees have been understudied in multicultural literature (Hope, 2015). Reasons for refugee flight, for example, are largely misunderstood and underrepresented in children's literature and classrooms (Dolan, 2014). At the same time, reasons for flight distinguish refugees from immigrants in legal claims for asylum as well as in policies impacting them upon transition to a new country. Among other factors "bureaucratic interests and procedures are themselves crucial determinants in the definition of labels like refugee" (Zetter, 1991, p. 41). Thus, representations of the legally significant reasons and circumstances for leaving home warrant analysis of refugee flight in children's literature and the related ideologically significant assumptions they may promote.

In this study, I employ a critical multicultural perspective (Botelho \& Rudman, 2009) and refugee critical race theory (Strekalova-Hughes, Bakar, Nash, \& Erdemir, 2018) to conduct a critical content analysis (Johnson, Mathis, \& Short, 2017) of 45 picturebooks featuring first-generation children from refugee backgrounds as main characters. The purpose of the study is to learn how (and if) refugee flight is represented in early childhood picturebooks. The study is guided by asking how and for what purposes children's literature represents refugee flight, attending to intersections of legal realities and literary narratives.

\section{Theoretical Framework}

This study draws on two theoretical frameworks: critical multicultural perspectives in children's literature (Botelho \& Rudman, 2009) and refugee critical race theory, RefugeeCrit (Strekalova-Hughes et al., 2018). A critical multicultural perspective (Botelho \& Rudman, 2009) sees children's texts as historical and cultural artifacts that represent and reproduce intersectional power dynamics (Johnson \& Gasiewicz, 2017). Every story has a unique context, highlighting "the dynamic and fluid nature of cultural experiences within unequal access to social power experienced by some groups within a society" (Johnson \& Gasiewicz, 2017, p. 29). For example, power dynamics are revealed by understanding which characters have agency. If agency intersects with cultural or experiential background (e.g., legal refugee status), it becomes ideologically significant (Stephens, 1992). This lens deepens the analysis of how (and if) refugee flight is represented, and how it is situated in complex cultural and historical contexts. Making ideological significance visible can empower teachers when navigating global-displacement issues in the classroom.

In children's literature, social group representations and accompanying assumptions are not random. The ideological underpinnings of portrayals of refugees are related to a wider discourse. Therefore, I employ a second emerging theoretical framework, RefugeeCrit, which aims to forefront refugee voices in shaping this discourse (Strekalova-Hughes et al., 2018). RefugeeCrit builds on refugee studies (e.g., Zetter, 1991; 2007) and critical race theory (CRT) in 
education (e.g., Ladson-Billings \& Tate, 1995; Ladson-Billings, 2013), a theory grounded in transformative scholarship of people of color (e.g., Brayboy, 2005; Solórzano, 1998; Solórzano \& Yosso, 2002). CRT originated in the field of legal studies (e.g., Bell, 1987; Crenshaw, 2011; Davis, 1989; Wing, 2016) as a way to name and challenge racially oppressive laws, policies, and systems. CRT changed the field of education, reshaping much of the research conducted with people historically experiencing legally and economically sanctioned racism. RefugeeCrit focuses CRT's attention on a different (but overlapping) population- refugees. This framework draws out specialized legal and economic mechanisms of oppression that inform discourses and dialogue with the lived realities of children whose experiences require legal protection of refugee status. RefugeeCrit also focuses on the purposes for which refugees tell their own status-related stories (e.g., legal claims for asylum, staying connected to homeland) and the purposes for which others co-opt those stories (e.g., increasing fundraising, resettlement cases). This tension may arise in children's literature: between empowering and honoring refugees' agential voices and using stories for personal gain or to (sub)consciously advance oppressive agendas. Methodologically, RefugeeCrit aims to shape intentional research supporting action for positive change and social justice for refugees. Tenets of RefugeeCrit mirror those of CRT (Ladson-Billings \& Tate, 1995; Ladson-Billings, 2013). Brayboy's work (2005) on Tribal critical race theory was instrumental in conceptualizing global context mentalities that apply to people from refugee backgrounds. The tenets most relevant to this study are as follows:

- Colonial, imperial, and racist mentalities are endemic in the global society and contribute to refugee flight;

- Legal refugee status and economic resettlement policies function as a mechanism of oppression and subordination;

- Need for agential voices and counter-narrative as colonial, imperial, and racist mentalities legally and economically attempt to chain refugee narratives and stories to their protective status and label;

- Social construction of race intersects with legal refugee status and geographic spaces;

- Intersectionality shapes the experiences of refugees at each social context and border crossing; and

- Anti-essentialism is critical for understanding refugee experiences and complex identities.

Like all extensions of CRT that continue to proliferate educational research, RefugeeCrit and related scholarship should be closely scrutinized and critiqued "as a way to protect the integrity of the legacy that scholars such as Derrick Bell, Kimberle Crenshaw, Richard Delgado, Cheryl Harris, Charles Lawrence, Mari Matsuda, Patricia Williams, and many others have sacrificed to develop and preserve" (Donnor \& Ladson-Billings, 2017, p. 207). 
RefugeeCrit offers a pointed interpretation of refugee-flight representations and related assumptions about children from refugee backgrounds. This framework can support teachers in text selection and meaningful critical literacy discussions.

\section{Literature Review}

The purpose of this literature review is to highlight the power of picturebooks representing children from refugee backgrounds and the urgency of critical content analysis that so far is missing from research of these texts. This section consists of four bodies of knowledge. First, I draw from the literature that addresses the necessity of literary representation of children from refugee backgrounds. Second, I discuss children's ability to access complexities arising from representations of global displacement in children's literature. Third, I describe the transformational purpose of having such texts available to children in the classroom. Finally, the section concludes with an overview of the current state of relevant children's literature research.

\section{Need for Representation}

Patricia: Are you sure you looked?

Alexander: Everywhere in there!

Patricia: She [the librarian] even helped me.

She said, "I guess we don't have any."

Alexandro: Did you tell her that's not fair?

(Vasquez, 2017, p. 1)

The above vignette features two kindergarten students of Dr. Vivian Maria Vasquez, who used a critical literacy framework to lead students to investigate cultural representations of themselves in their school library. At the heart of representations reflecting the complexity in shared spaces, including literary texts, is the project of democratization of our ways of being and doing (Vasquez, 2017). Since the world is a "socially constructed text that can be read" and represented in literary texts, early childhood readers can think and believe specific things about how the world is, including their own significance in it (Vasquez, 2017, p. 3).

An additional layer of complexity accompanies children from refugee backgrounds in children's literature: some argue that experiences that qualify someone for asylum and protection may not be appropriate material for young readers. Such experiences often involve violence, wars, or ongoing persecution (e.g., based on ethnic, religious, or political affiliation or refusal to affiliate with a particular group). Hope (2015) describes a protest against a children's television 
show that featured war-related children's experiences and teacher hesitation about the inclusion of asylum-related books.

The debate about the developmental-appropriateness of refugee experiences for children's literature misleadingly assumes that children have not had these experiences themselves. Critical literacy "arises from the social and political conditions that unfold in communities in which we live" (Vasquez, 2017, p. 1 ), an observation that certainly applies to children from refugee backgrounds. If refugee status is invisible in children's literature, it erases the presence of children from refugee backgrounds and further implies that their existence is of no relevance to their peers.

Fortunately, the number of picturebooks about people from refugee backgrounds is growing (Hope, 2015), which will increase visibility and democratic representation. These trends indicate the necessity of conversations about what children from refugee backgrounds and their peers can learn from stories: power dynamics surrounding displacement and actions they can take toward global social justice.

\section{Internalizing and Questioning Representation}

Children can vicariously internalize beliefs represented in texts as well as consciously challenge representations and "rewrite" stories through critical discussion. Stephens (1992) argues that texts are designed to influence children's beliefs: "The use of story as an agent of socialization is a conscious and deliberate process" (p. 9). Picturebooks represent how "children's writers often take upon themselves the task of trying to mould audience attitudes into desirable forms, which can mean either an attempt to perpetuate certain values or to resist socially dominant values which particular writers oppose" (Stephens, 1992, p. 3).

Critical literacy scholars (Vasquez, 2017) argue that children can resist encoded messages that imply group superiority. Botelho and Rudman (2009) suggest that children of any age can be critical multicultural readers who can question the quality of complex multicultural representations. How teachers engage with literature in the classroom must reflect their belief in children's critical reading abilities and their own abilities to facilitate discussions beyond the "face value" of the text. Otherwise, children will be developing safe close-reading skills rather than "world-reading" skills that have a greater potential to rewrite social reality.

Reasons for leaving home are inherently legally, culturally, socially, historically, economically, and politically complex. While children may need teachers' support unpacking the world beyond the text, they are capable of questioning representational patterns and also deliberating on actions.

\section{From Understanding to Action}

Critical literacy's goal is to equip children for participation in a just world and to promote social change. For example, Vasquez (2017) asks herself, "Are my students able to participate in the world differently as a result of the work we have 
done?" (p. 3). Children's literature informs how children see what kind of justice is needed and may also suggest actions necessary to achieve this vision.

When it comes to children's literature that represents children from refugee backgrounds, we have yet to figure out what transformative actions children are inspired to take and what kind of justice they believe is needed. Coughlan argues children need stories about refugees because "these inspiring books encourage empathy in their readers, which in turn has the potential to stir them to action" (as cited in Hope, 2016, p. 17). More importantly, Dolan (2014) suggests that picturebooks expose children to "issues related to the history of racism, sexism, classism, homophobia and religious intolerance, and how those forms of oppression have affected different communities" (p. 103), which can inspire actions that directly address these issues.

\section{Previous Research}

Scholars have examined portrayals of children from refugee backgrounds in literary accounts (e.g., Johnson \& Gasiewicz, 2017). The study of these representations, however, is complicated by terminology that describes children who are born outside of a country where they are currently located. The majority of studies that analyze texts featuring protagonists from refugee backgrounds combine them with texts about voluntary immigration (Johnson \& Gasiewicz, 2017). For example, one study combined protagonists that "voluntarily leave their homes or are involuntarily forced to do so; they are emigrant, immigrants, or trafficked youth" (Parsons, 2016, p. 19). I argue that while immigration and displacement produces a similar result based on environmental events and, for example, armed conflict and cultural cleansing as Johnson and Gasiewicz (2017) suggest, there are also unique differences, especially around reasons for flight. Circumstances under which children leave their "geographically bound physical space" (Kibreab, 1999) necessitate precise text selection criteria for this study that go beyond "journeying" across territories as a common denominator.

Johnson and Gasiewicz (2017) examined displacement circumstances and found that "each context is slightly different, but many of the obstacles are similar" (p. 39). In some stories, protagonists are displaced due to war or conflict, while others highlight main characters who voluntarily leave. While the examination of "leaving home" was not the study's focus, its major finding suggests that upon displacement, "the United States is seen as a safe place, a place of welcome, and a place of hope" (p. 39). This idyllic assumption positions power outside of these youth's homelands.

Sung, Fahrenbruck, and López-Robertson (2017) studied representations of immigration in children's literature, which included texts about the displacement of youth from refugee backgrounds. They found that challenges at home (e.g., encroaching war) and broken-down family structures (e.g., the death of a father or parent separation) were the primary reasons for departure. Depictions of "tensions, conflicts, abuse, sadness, and despair" surrounding the need to leave home distance readers from characters and cultivate a "sympathetic response for 
readers through feelings of pity for immigrants and a sense of superiority for their own way of life" (Sung, Fahrenbruck, \& López-Robertson, 2017, p. 56).

Existing research provides a glimpse into the circumstances accompanying refugee flight and related assumptions about power and agency. For teachers seeking to develop young children's critical literacy skills around this culturally, historically, legally, and politically complex topic, more research is needed. This study aims to offer insights related to refugee flight through an inquiry process described in the next section.

\section{Methodology}

In children's literature, "critical content analysis involves bringing a critical lens to an analysis of a text or group of texts in an effort to explore the possible underlying messages within those texts, particularly as related to issues of power" (Short, 2017, p. 6). Implications of studies using this methodology often aim to "challenge conditions of inequity" (Short, 2017, p. 1) through impacting future literary representations, teachers' informed text selection, and critical literacy discussions in the classroom. This study employs critical content analysis to explore embedded issues of power surrounding representation of refugee flight in a group of texts to challenge inequity.

Critically evaluating literary texts is a complex task, since literature as art is "ideologically ambivalent, humanizing in some ways and dehumanizing in others" (Nel, 2018, p. 359). In other words, any story under analysis can be a masterpiece in some ways and a subtle propagation of prejudice in others (Nel, 2018). This study is not aiming to find a "perfect story" or sanction all stories that have overt damaging messages. The aim here is to deepen understanding of elements within any story that teachers can critically distinguish and challenge in the classroom.

\section{Text Selection Criteria}

This study analyzes 45 narrative picturebooks featuring children from refugee backgrounds. Original searches for children's literature about refugees yielded nearly 300 texts. The majority of these texts were for young adolescent readers and were excluded to focus on picturebooks targeting early childhood audience. I used the following inclusion criteria to narrow the scope: firstgeneration children from refugee backgrounds as main characters, narrative/story picturebooks (chapter books, non-fiction picturebooks, or poems were excluded), and picturebooks that referred to conflicts after WWII.

Distinguishing texts about immigration from those related to asylum and refugee protective status was a challenging task. Books containing the word "refugee" in the title, description, or text itself were included, even if the narrative focused exclusively on other aspects of the protagonist's identity. For example, Teacup (Young \& Ottley, 2015) could be about migration in general, but was included since the description mentioned relevance to refugees. Stories that could be about voluntary immigration, such as One Green Apple (Lewin, 2006), and The 
Name Jar (Choi, 2003), were excluded from analysis. I included books which referred to relevant experiences without naming the main characters "refugees" or "asylum seekers." If a text referred to circumstances warranting refugee status even if characters did not seek it or were officially denied, the book was still included. The experiences of people rather than official designations informed text selection for this study.

\section{Data Analysis}

My initial set of research questions was transformed through recursive interaction with data and theory. Following Short's (2017) critical content analysis process, I first identified a set of theories that promised the most effective analytical lens through which to examine representations of children from refugee backgrounds. Next, I engaged in a broad reading of socio-historical and cultural contexts of the social breakdowns featured in the stories. Third, I reviewed studies that included some of the same picturebooks (e.g., Hope, 2016); studies that had similar purposes to my own (e.g., Braden \& Rodriguez, 2016); and, finally, broad scholarly work applying the same theoretical frameworks. Fourth, I identified specific tenets within the theoretical assemblage which sharpened my reporting lens on refugee flight, rather than general intersectional themes of power and agency throughout the stories. Finally, I conducted a close reading within and across picturebooks with my theoretical tenets and relevant socio-historical and cultural contexts in mind.

The initial close reading aimed to identify units of study within the stories. The unit of analysis in a critical content analysis of children's literature (Short, 2017) could be dialogues and interactions between particular characters, actions and thoughts of a specific character, or key incidents related to research questions. My unit of analysis in this study was the critical incidents of leaving home within each text. I paid close attention to whether stories included fleeing home, and if yes, why protagonists left home, how they left, and any relevant thoughts/feelings/questions. The critical incidents within each story were carefully documented and recorded.

During the next phase of close reading I closely examined the units of study, making notes and "gradually moving toward identifying significant issues, themes, or categories" (Short, 2017, p. 12). I attended to who had power and agency and what related assumptions could be made about refugee flight and refugees. For each major theme that emerged through analysis, I wrote extensive theoretical memos, describing the theme, including examples from within and across texts, and juxtaposing it with literature and theoretical tenets. After the close exploration of units of analysis, I reread stories in the study in their entirety, contextualizing identified themes. 


\section{Findings and Discussion}

I found that picturebook representations of refugee flight bind it to legal realities, depicting fleeing home within the frame of bureaucratic processes and refugee as an institutionally imposed standardized identity. Refugee flight is embedded in a forced-to-flee narrative accompanied by persecution, war, or violence and well-founded fear narratives (UN General Assembly, 1951). While a leaving-home-for-safety narrative is central to many stories, the deeper reasons behind refugee flight are mostly veiled as institutionally irrelevant. In the following sections, I unpack these findings and agency and power assumptions (Johnson, Mathis, \& Short, 2017) about refugee populations.

\section{"Forced-to-Flee" Narrative}

The overwhelming majority of stories include "forced-to-flee" narrative (Table 1), adhering closely to the legal definition of a refugee as "someone who has been forced to flee his or her country" (USA for UNHCR, 2019). Fleeing home is frequently depicted as unwanted, unplanned, and necessary. As exemplified in Azzi in Between (Garland, 2013), leaving home is not a choice that children and their families plan for and make willingly:

But one evening, the phone rang. Father listened to the message and his face was pale. He turned to his family. "Quick! In the car! No time to lose, no time to pack. We must leave the country. We are in terrible danger!"

Azzi's experience speaks to the pervasive portrayal of refugee flight and the particular way of doing so, signaling the unwanted and unplanned departure from home, caused by danger. When Hope (2008) explored identities of children from refugee backgrounds in children's literature, she included "one day we had to run" in the title. This represents the cemented link between refugee identity and flight. Employing a critical multicultural analysis (Botelho \& Rudman, 2009), the prevalence of flight depictions in this study's stories denies refugee agency as they reactively leave homes and privileges those who do not have to flee.

If the purpose of children's literature is to reaffirm identities of children from refugee backgrounds, why would these stories inevitably include a brief description of unwanted, unplanned, and necessary flight connected to their legal status as if the descriptions were lifted from the UNHCR handbook on asylum procedures? As a parallel example, imagine stories designed to reaffirm women's identities (who happen to be married) always including an altar scene where they say "yes" and sign a marriage certificate. The inclusion of flight-narratives appears to be a nod to legal refugee status, explaining to unfamiliar readers what refugee status is and, perhaps, that refugees are forced to come to the reader's country. This representation avoids the possibility that refugees purposely chose to come to claim the dreams and opportunities of the new country. As far as attitudes and actions that stories may want to promote (Stephens, 1992), it appears that welcoming refugees is the desired action. This action is easier to take when 
refugees are not framed as fleeing to purposefully obtain opportunities in the new country.

At the same time, flight is "not necessarily the central aspect of the complex, culturally and historically situated, identities that families want to sustain and pass on to their children" (Strekalova-Hughes \& Wang, 2019). It is no surprise that some parents from refugee backgrounds prefer that teachers know little about their child's experience entering the country because it "is not necessary. What matters is that my child gets the same education as the other, non-refugee children" (Szente, Hoot, \& Taylor, 2006, p. 17). At home, families may discuss how and why they left their country. For example, families may want to inspire children to change things in their country of origin, like a son who dreamt of becoming the president of South Sudan to make it better for the people, thereby preventing future flight (Strekalova-Hughes \& Wang, 2019). These conversations may differ from representations of refugee flight in the majority of picturebooks.

\section{Prominence of "Persecution, War, or Violence"}

The prevalence of refugee flight in the stories described above is strongly connected to another finding in these books: conflict (persecution, war, or violence) as a prominent feature (Table 1). This element is connected to the UN's definition of a refugee as "someone who has been forced to flee his or her country because of persecution, war, or violence" (USA for UNHCR, 2019). Although conflict appears to varying degrees, it is almost an inevitable feature of these stories.

The majority of the stories explicitly name "war" or "civil war" as a critical incident that leads main characters to flee home. In The Stepping Stones: $A$ Refugee Family's Journey, the protagonist narrates, "The war came to our country. Life in our village changed" (Ruums \& Raheem, 2016). Other picturebooks depict violence as a reason to flee. In The Colour of Home (Hoffman \& Littlewood, 2002), the protagonist recalls the reasons his family had to leave: "the noise, the flames, the bullets and the awful smell of burning and blood" as well as his uncle's death. Finally, these stories depict targeted persecution. In Mohammed's Journey (Robinson, Young, \& Allan, 2009), the Kurdish family fled because Saddam's soldiers came into their house and "Saddam hated the Kurds." Only rarely do stories omit conflict (e.g., My Name is not Refugee by Milner (2017) and Joseph's Big Ride by Farish \& Daley (2017). Even in such cases, the conflict that made someone leave is sometimes implied in text or illustrations.

Conflict is central to narrative structures binding children to their legal protective status. The purpose of the narrative might be to establish the difference between immigrants and refugees. The overwhelming presence of persecution, war, or violence, (even though often followed by resilience), however, unmasks the metanarrative associated with a legal definition of a refugee and institutionalized procedure of claim processing. Readers can assume that violence defines children from refugee backgrounds more than other experiences, cultures, or personal qualities. As a teacher educator, I encountered this assumption when my student teacher was advised to give up on a learner from a refugee background because "he comes from a culture of violence." This is an example of what RefugeeCrit 
points out as a dissonance between the purpose of stories when they are told by refugee families and the purposes of telling their stories by others.

RefugeeCrit (Strekalova-Hughes et al., 2018), following CRT's lead (Ladson-Billings \& Tate, 1995; Ladson-Billings, 2013), urges researchers to foreground "agential voices and stories of children and families from refugee backgrounds to gain perspectives on their lived experiences and complex identities that counter the dominant discourses tied to a unifying refugee status" (p. X). Some families tell stories that are not limited to the violence driving their departure from home and focus on sustaining cultural values and histories. Instead of inevitably including conflict and flight as required passwords to write about a child statused as a "refugee," stories could be "honoring and valuing the practices that were important to families and communities before displacement and might be important to the future generations after resettlement" (Strekalova-Hughes \& Wang, 2019, p. 8).

\section{Fleeing from "Well-founded Fear"}

In this research, I also found that conflict-related physical and psychological damage in the stories provides grounds for the "well-founded fear" requirement of asylum claims (UN General Assembly, 1951) and refugee status procedures (UNHCR, 1979). Stories in the study provide myriad examples of conflict-related physical, psychological, and cultural damage that represent a legitimate threat to children and their families (Table 1). For example, text and illustrations depict physical damage through explosions, burning or destroyed homes, vehicles, or entire villages/towns (e.g., The Banana-Leaf Ball; The Silence in the Mountains). Conflict-related loss of loved ones has a psychological impact on surviving protagonists, as in the case of Playing War: "I wasn't a soldier. Nobody in my family was. But we got in the war anyway, when they blew up our house. My father, my mother, and my little brother were in the house and they all died" (Beckwith \& Lyon, 2005). Permanent or temporary family separation emerged as another conflictrelated impact. A Song for Cambodia describes permanent separation of the protagonist from the mother: "Arn clutched his mother, but soldiers forced them apart. She cried out for her children, then was gone. Arn would never hear her voice again" (Lord \& Arihara, 2015). In Azzi in Between, separation is painful and temporary, since the family reunites in the country of resettlement (Garland, 2013).

Cultural damage surfaced as another conflict-related impact. In The Treasure Box (Wild \& Blackwooda, 2017), the enemy bombed the library filled with culturally significant books. A Song for Cambodia also captures the loss of cultural practices and heritage: "Songbirds stopped chipping, and monks were silenced. Art, religion, and music disappeared from people's lives" (Lord \& Arihara, 2015).

The stories employ persuasive depictions of well-founded fear, loss, and trauma. Hope (2008) suggests such narratives provide powerful ways to teach peer empathy. My concern, however, is that nearly every story with a child from a refugee background describes empathy- and sympathy-worthy experiences. While peers and teachers of children from refugee backgrounds might gain from this and learn empathy, sympathy places the subject in an inferior position. It is hard to 
imagine refugee parents wanting other children to learn sympathy or empathy at their children's expense.

These well-founded fear narratives may also perpetuate assumptions that children from refugee backgrounds are defined entirely by their traumatic experiences. "Trauma" may become an overdiagnosis in some classroom situations. For example, teachers may believe children are acting out due to trauma, not because of a pedagogical error. They may also interpret withdrawal as a PTSD symptom rather than as a symptom of missing a home culture rendered invisible by the school curriculum. In either case, teachers' classroom expectations shift when they assume a child is less capable. Emphasis on individual cultures of children from refugee backgrounds (Strekalova-Hughes, 2017; Strekalova-Hughes \& Wang, 2017) might be a more productive focus to educate for democratic society (Sleeter, 2018) rather than prescribing unifying damages and institutionally perceived needs (Zetter, 1991).

\section{Reasons for "Persecution, War, or Violence"}

Asylum-seeking reasons require more understanding in societal discourse in general and in critical literacy classroom discussions in particular (Dolan, 2014). The findings above demonstrate that refugee flight in picturebooks occurs largely in response to conflict (persecution, war, or violence). The next step in understanding refugee flight is to examine how the reasons for conflict are represented. This is a crucial question since the answers may encourage readers to target global injustices that cause refugee flight in the first place. If children's literature is supposed to deepen understandings of increasing refugee flight, my final finding seemingly contradicts this goal. Only a fraction of the picturebooks attempted to explain the root cause of the featured conflict within the stories (Table 1).

The more prevalent way of describing conflicts includes a matter-of-fact approach as if causeless conflicts have just been a part of the country's history (ongoing causeless conflict) or happen suddenly for no apparent reason (sudden causeless conflict). In Ali's Story, the protagonist gives his reasons for leaving: "There was always so much fighting going on, but the war started to get worse" (Maldonado \& Glynne, 2015). The story does not mention the reason for the ongoing conflict; thus, the war is a given condition of his homeland-almost a topographical feature. The fact that the war has "always" been happening may foster assumptions that bad things just happen in Ali's country (Afghanistan).

Brothers in Hope (Williams \& Christie, 2005) illustrates the second representational scenario (sudden causeless conflict): "I was far from home tending my animals when my village was attacked. I could hear bangs like thunder and see flashing lights in the distance. Suddenly an airplane was circling above." Authors may use the sudden nature of conflict to show how bad things can happen to anyone going about their day. Since most of the characters are from foreign countries, however, readers can assume that this occurs only in "those" countries.

This assumption deepens when causeless-conflict countries are contrasted with "safe" places, like Europe and the United States. For example, in Gervelie's 
Journey, "There were guns everywhere and shooting all the time... . So Dad and I decided that we should escape to Europe" (Robinson, Young, \& Allan, 2008). In My Name is Sangoel, the protagonist's country is contrasted with the stable and safe United States: "In America you will have a new home. . . . You will never again have to escape in the night" (Williams, Mohammed, \& Stock, 2009).

Less prevalent conflict descriptions include developmentally appropriate explanations about why conflicts occur (Table 1). In Dia's Story Cloth (Cha, Cha, \& Cha, 1998), the story indicates that cultural oppression is the reason for conflict and resulting flight: "The ancient Chinese government wanted to change the way the Hmong lived. But my people would not give up their culture." Even in these stories, however, narratives lack descriptions or explanations that "safe" countries' international interference might be at fault for creating or extending conflicts described in the books.

Since institutions handling refugee resettlement are less concerned with addressing causes of conflict, reasons for conflict become institutionally irrelevant. If stories omit conflict reasons that cause refugee flight, readers may make several assumptions. First, they may assume conflicts happen elsewhere; some countries are broken and some function well. Broken counties spit out refugees and working countries take them in. Readers can assume that, since most of the characters are from foreign countries and are people of color, bad things happen to "those" people in unstable countries. This leads to a second assumption: if conflicts happen without reason, we cannot tackle the root causes leading to refugee flight but only address the aftermath. A third assumption equates to a denial of responsibility for international interference that contributes to starting the conflict or extending its length (e.g., providing weapons to different sides of the conflict to destabilize the region).

From the perspective of power and privilege in children's literature (Stephens, 1992; Botelho \& Rudman, 2009), the simplified duality of countries as either safe or unsafe pathologizes some countries and privileges others. Similarly, Braden and Rodriguez (2016) suggest that children's literature tends to represent utopian societies where children immigrate, rarely addressing social justice issues involving race, gender, poverty, and immigration status that continue to affect their lives in the countries that are safer for some, but not all. In stories focused on refugee flight, representations of conflict as random, spontaneous acts in some places and not others ignore the realities of socio-historical and cultural complexities of both sets of countries.

\section{Conclusions}

This study explores representations of and assumptions about refugee flight in picturebooks with young protagonists from refugee backgrounds. Viewed through the lens of those personally unfamiliar with displacement, the majority of the stories are a success of forming a "bureaucratic identity" of refugees (Zetter, 
1991, p. 39). The texts illustrate legal immigration terminology and processes under the UN Refugee Convention of 1951 by establishing forced-to-flee narratives, centering persecution, and highlighting damage and trauma that corroborate wellfounded fear behind flight. This definition no longer represents the complexity of global displacement (Zetter, 2007) and, reaffirmed in children's literature, prioritizes the iconic image of a refugee (Strekalova-Hughes et al., 2018). The bureaucratic representations of refugee flight assume that children from refugee backgrounds are defined by their status more than by other aspects of identity, culture, and experiences. While the nature of departure from home is important to families for many personal and cultural reasons, the purpose of telling these stories is not a clerical exercise. Families tell stories that go beyond the flight experience to honor human qualities, experiences, and practices which "were important to families and communities before displacement and might be important to the future generations" (Strekalova-Hughes \& Wang, 2019, p. 8).

It would be incorrect to conclude that persecution, war, or violence do not impact children from refugee backgrounds. Some children experience trauma that exceeds anything depicted in picturebooks. Other families flee before children experience such events; their stories may not sound "refugee enough" in comparison, thus devaluing their pain and provoking imposter feelings. Regardless of these circumstances, both sets of families are prescribed the same essentialized identity and a unified legally bound experience.

The final finding of this study is that in the majority of the stories, reasons for conflicts are invisible. This might create assumptions that flight-causing conflicts happen for no reason to ethnically and racially different children in other countries, that other countries are pathologically predisposed to conflicts, and that colonial and imperial mentalities of one's own country could not have contributed to refugee flight elsewhere. Agency and power may appear to be bestowed privileges upon citizens of "safe" countries that receive those who flee (Johnson \& Gasiewicz, 2017).

Stories focused on flight often invoke empathy among readers (Hope, 2016). This empathy can promote a welcoming and accepting environment for refugees after resettlement. As the narratives mostly omit root causes of conflicts, however, only their aftermath can be a target of the readers' actionable empathy. While this action might be helpful to families currently in flight and to refugee resettling agencies, it may do little to raise critically educated citizens who can prevent conflict in the first place.

\section{Implications}

A student who read all the books in this study shared, "These books make me so sad. Those poor children. I tell all of my friends to read them and be grateful for the life they have." This is probably not the intended reaction most authors and teachers would wish for when writing or teaching these stories. I offer two 
implications of this study that may support efforts to promote global social justice among early childhood audience instead of developing "a sense of superiority for their own way of life" (Sung, Fahrenbruck, \& López-Robertson, 2017, p. 56).

\section{Diversity of Representation}

Children and families from refugee backgrounds who have personal experiences with flight and resettlement may not need as many bureaucratic illustrations of immigration terminology that appear plentiful in the stories. Authors could diversify current representations of young protagonists beyond experiences directly related to legal refugee status-beyond conflict, flight, and trauma, adding stories where funds of knowledge, culture, or admirable character traits beyond resilience take center stage, without having refugee flight as a required feature. Families and children could add own representation in the stories for authentic purposes. Such stories may add identity choices in children's literature representations.

Teachers could select texts featuring diverse representations as described above or have critical literacy discussions around assumptions that arise from texts that center one aspect of identity. Critical questions that could drive text selection are, "Does the book overly focus on legal refugee definitions? Is there room to have pride as a refugee after finishing the story? Can the refugee protagonist be sincerely admired? Can peers see desired skills and abilities in the protagonist?"

\section{Unpacking Context of Refugee Flight}

Current research offers suggestions for how teachers may lead discussions about refugee flight in picturebooks (Hope, 2016). However, these implications appear to be missing a critical perspective. To move the discussion in the field forward, I suggest that describing context of refugee-flight might be essential in confronting global social injustices. It may not be sufficient to say that a conflict happens because one side attacks the other; it would be helpful to provide deeper rationales that underscore human injustices responsible for conflicts, including understandings of how other countries may be contributing to refugee flight. Authors could include developmentally appropriate narratives about human moral faults related to conflict, as well as virtues, within complex socio-historical and cultural contexts about conflicts leading to flight.

Since there are not many counter-narratives in picturebooks, teachers could use existing stories through a critical literacy lens (Vasquez, 2017). For example, they might facilitate classroom discussions in which wars, violence, and persecution are not taken for granted. To resist "discourses of Othering" (Dervin, 2016, p. 43), teachers could think together with students about social interactions in their own classrooms that might resemble those that lead to the conflict and flight in foreign countries featured in the stories, such as excluding classmates due to perceived differences, coveting a peer's classroom materials, or being a line leader who ignores requests of the rest of the line. Emphasizing social breakdowns that cause conflicts might help prevent more injustices than would just emphasizing how to act afterward. Introducing circumstances where people make 
good or bad choices and why they do so may help children learn more powerful skills than empathy alone.

Teachers and students could also consider grappling with their country's economic gains and global interactions/interference in stories they read. Opportunities for deeper lessons might be missed by focusing on conflicts that appear to "just happen." Discussions of the missing stories could potentially work towards creating citizens resistant to racist, colonial, and imperialist mentalities (Paris \& Alim, 2017) rather than empathetic hosts of refugees their country has helped create. To parallel Freire's thought (1972), such critical discussions may support education for liberation, not domestication.

\section{References}

Bell, D. (1987). And we are not saved: The elusive quest for racial justice. New York, NY: Basic Books.

Botelho, M. J., \& Rudman, M. K. (2009). Critical multicultural analysis of children's literature: Mirrors, windows, and doors. New York, NY: Routledge.

Braden, E. G., \& Rodriguez, S. C. (2016). Beyond mirrors and windows: A critical content analysis of Latinx children's books. Journal of Language and Literacy Education, 12(2), 56-83.

Brayboy, B. M. J. (2005). Toward a tribal critical race theory in education. The Urban Review, 37(5), 425-446.

Crenshaw, K. W. (2011). Twenty years of critical race theory: Looking back to move forward. Connecticut Law Review, 43(5), 1253-1352.

Davis, P. C. (1989). Law as microaggression. Yale Law Journal, 98(8), 15591577.

Dervin, F. (2016). Interculturality in communication and education: A theoretical and methodological toolbox. London, UK: Palgrave Macmillan.

Dolan, A. (2014). Intercultural education, picturebooks and refugees: Approaches for language teachers. Children's Literature in English Language Education, 2(1), 92-109.

Donnor, J. K., \& Ladson-Billings, G. (2017). Critical race theory and the postracial imaginary. In N. K. Denzin \& Y. S. Yvonna (Eds.), Handbook of qualitative research ( $5^{\text {th }}$ ed., pp. 195-213). Thousand Oaks, CA: SAGE.

Freire, P. (1972). Education: Domestication or liberation? Prospects, 2(2), 173181.

Gorski, P. C. (2008). Good intentions are not enough: A decolonizing intercultural education. Intercultural Education, 19(6), 515-525. 
Hope, J. (2008). 'One day we had to run': The development of the refugee identity in children's literature and its function in education. Children's Literature in Education, 39(4), 295-304.

Hope, J. (2015). 'A well-founded fear': Children's literature about refugees and its role in the primary classroom (Unpublished doctoral dissertation). Goldsmiths, University of London, London, UK.

Hope, J. (2016). "The soldiers came to the house": Young children's responses to The Colour of Home. Children's Literature in Education, 49(3), 302-322.

Johnson, H., \& Gasiewicz, B. (2017). Examining displaced youth and immigrant status through critical multicultural analysis. In $\mathrm{H}$. Johnson, J. Mathis, \& K. G. Short (Eds.), Critical content analysis of children's and young adult literature (pp. 28-43). New York, NY: Routledge.

Johnson, H., Mathis, J., \& Short, K. G. (Eds.). (2017). Critical content analysis of children's and young adult literature: Reframing perspective. New York, NY: Routledge.

Kibreab, G. (1999). Revisiting the debate on people, place, identity and displacement. Journal of Refugee Studies, 14(4), 384-410.

Ladson-Billings, G. (2013). Critical race theory-What it is not! In M. Lynn \& A. Dixson (Eds.), Handbook of critical race theory in education (pp. 54-67). New York, NY: Routledge.

Ladson-Billings, G., \& Tate, W. (1995). Toward a critical race theory of education. Teachers College Record, 97(1), 47-6

Nel, P. (2018). Migration, Refugees, and Diaspora in Children's Literature. Children's Literature Association Quarterly 43(4), 357-362.

Paris, D., \& Alim, H. S. (Eds.). (2017). Culturally sustaining pedagogies: Teaching and learning for justice in a changing world. New York, NY: Teachers College Press.

Parsons, L. T. (2016). Storytelling in global children's literature: Its role in the lives of displaced child characters. Journal of Children's Literature, 42(2), 19-27.

Short, K. G. (2017). Critical content analysis as a research methodology. In H. Johnson, J. Mathis, \& K. G. Short (Eds.), Critical content analysis of children's and young adult literature (pp. 1-15). New York, NY: Routledge.

Solórzano, D. G. (1998). Critical race theory, race and gender microaggressions, and the experience of Chicana and Chicano scholars. International Journal of Qualitative Studies in Education, 11(1), 121-136.

Solórzano, D. G., \& Yosso, T. J. (2002). Critical race methodology: Counterstorytelling as an analytical framework for education research. Qualitative Inquiry, 8(1), 23-44. 
Sleeter, C. E. (2018). Multicultural education past, present, and future: Struggles for dialog and power-sharing. International Journal of Multicultural Education, 20(1), 5-20.

Stephens, J. (1992). Language and ideology in children's fiction. New York, NY: Longman.

Strekalova-Hughes, E. S. (2017). Comparative analysis of intercultural sensitivity among teachers working with refugees. Journal of Research in Childhood Education, 31(4), 561-570.

Strekalova-Hughes, E., Bakar, A. Nash K., \& Erdemir, E. (2018, April). Refugee critical race theory in education: An emerging ontological and epistemological lens. Paper presented at the annual meeting of the American Education Research Association, New York, NY.

Strekalova-Hughes, E. S., \& Wang, X. C. (2017). Intercultural experiential continuum: A case study of early childhood teachers working with refugee children. Journal of Early Childhood Education Research, 6(1), 61-88.

Strekalova-Hughes, E. S., \& Wang, X. C. (2019). Perspectives of children from refugee backgrounds on their family storytelling as a culturally sustaining practice. Journal of Research in Childhood Education, 33(1), 6-21.

Sung, Y. K, Fahrenbruck, M. L., \& López-Robertson, J. (2017). Using intertextuality to unpack representations of immigration in children's literature. In H. Johnson, J. Mathis, \& K. G. Short (Eds.), Critical content analysis of children's and young adult literature (pp. 44-60). New York, NY: Routledge.

Szente, J., Hoot, J., \& Taylor, D. (2006). Responding to the special needs of refugee children: Practical ideas for teachers. Early Childhood Education Journal, 34(1), 15-20.

Vasquez, V. M. (2017). Critical literacy across the K-6 curriculum. New York, NY: Routledge.

UNHCR (2018a). Refugees are not the crisis. It's the narratives we tell about them. Retrieved from http://www.unhcr.org/innovation/

UNHCR (2018b). Global trends: Forced displacement in 2017. Retrieved from http://www.unhcr.org

UNHCR (1979). Handbook on procedures and criteria for determining refugee status under the 1951 Convention and the 1967 Protocol Relating to the Status of Refugees. Retrieved from https://www.unhcr.org

USA for UNHCR (2019). Refugee facts. What is a refugee? Retrieved from https://www.unrefugees.org/

UN General Assembly (1951). Convention relating to the status of refugees. United Nations, Treaty Series, 189. Retrieved from http://www.refworld.org 
Wing, A. K. (2016). Is there a future for critical race theory? Journal of Legal Education, 66(1), 44-54.

Zetter, R. (1991). Labelling refugees: Forming and transforming a bureaucratic identity. Journal of Refugee Studies, 4(1), 39-62.

Zetter, R. (2007). More labels, fewer refugees: Remaking the refugee label in an era of globalization. Journal of Refugee Studies, 20(2), 172-192. 
Table 1

\section{Appendix}

Picturebooks and Themes

\begin{tabular}{|c|c|c|c|c|}
\hline Book/author and illustrator & $\begin{array}{l}\text { Forced-to- } \\
\text { Flee }\end{array}$ & $\begin{array}{l}\text { Persecution } \\
\text {, War, or } \\
\text { Violence }\end{array}$ & $\begin{array}{l}\text { Well- } \\
\text { founded } \\
\text { Fear }\end{array}$ & $\begin{array}{l}\text { Missing } \\
\text { Reasons for } \\
\text { Conflict within } \\
\text { Narratives }\end{array}$ \\
\hline $\begin{array}{l}\text { A Song for Cambodia by Michelle } \\
\text { Lord and Shino Arihara }\end{array}$ & $X$ & $X$ & $X$ & $\mathrm{n} / \mathrm{a}$ \\
\hline $\begin{array}{l}\text { Adriana's Angels by Ruth Goring } \\
\text { and Erika Meza }\end{array}$ & X & $\mathrm{n} / \mathrm{a}$ & X & $\mathrm{X}$ \\
\hline $\begin{array}{l}\text { Ali's Story by Salvador } \\
\text { Maldonado and Andy Glynne }\end{array}$ & $X$ & $X$ & $X$ & $X$ \\
\hline $\begin{array}{l}\text { Azzi in Between by Sarah } \\
\text { Garland }\end{array}$ & X & $X$ & $X$ & $X$ \\
\hline $\begin{array}{l}\text { Brothers in Hope: The Story of } \\
\text { the Lost Boys of Sudan by Mary } \\
\text { Williams and R. Gregory Christie }\end{array}$ & $X$ & $X$ & $X$ & $X$ \\
\hline $\begin{array}{l}\text { Calling the Water Drum by } \\
\text { LaTisha Redding and Aaron } \\
\text { Boyd }\end{array}$ & $\mathrm{n} / \mathrm{a}$ & $\mathrm{n} / \mathrm{a}$ & $\mathrm{n} / \mathrm{a}$ & $X$ \\
\hline $\begin{array}{l}\text { David's Journey: The story of } \\
\text { David Jal, one of the Lost Boys of } \\
\text { Sudan by David Jal, Laura K. } \\
\text { Jacobs and Tracy Bezesky }\end{array}$ & $X$ & $\mathrm{X}$ & $\mathrm{X}$ & $\mathrm{n} / \mathrm{a}$ \\
\hline $\begin{array}{l}\text { Dia's Story Cloth by Dia Cha, } \\
\text { Chue, and Nhia Thao Cha }\end{array}$ & $X$ & $X$ & $X$ & $\mathrm{n} / \mathrm{a}$ \\
\hline $\begin{array}{l}\text { Gervelie's Journey: A Refugee } \\
\text { Diary by Anthony Robinson, } \\
\text { Annemarie Young, and June } \\
\text { Allan }\end{array}$ & $X$ & $X$ & $X$ & $X$ \\
\hline $\begin{array}{l}\text { Gleam and Glow by Eve Bunting } \\
\text { and Peter Sylvada }\end{array}$ & $\mathrm{X}$ & $\mathrm{X}$ & $\mathrm{X}$ & $\mathrm{n} / \mathrm{a}$ \\
\hline $\begin{array}{l}\text { Half Spoon of Rice by Icy Smith } \\
\text { and Sopaul Nhem }\end{array}$ & $X$ & $X$ & $X$ & $\mathrm{n} / \mathrm{a}$ \\
\hline $\begin{array}{l}\text { Hamid's Story by Andy Glynne } \\
\text { and Tom Senior }\end{array}$ & $X$ & $X$ & X & $\mathrm{n} / \mathrm{a}$ \\
\hline $\begin{array}{l}\text { Hamzat's Journey: A Refugee } \\
\text { Diary by Anthony Robinson, } \\
\text { Annemarie Young, and June } \\
\text { Allan }\end{array}$ & $X$ & $\mathrm{X}$ & $X$ & $X$ \\
\hline $\begin{array}{l}\text { Home and Away by John } \\
\text { Marsden and Matt Ottley }\end{array}$ & $X$ & $X$ & $X$ & $\mathrm{X}$ \\
\hline
\end{tabular}




\begin{tabular}{|c|c|c|c|c|}
\hline $\begin{array}{l}\text { How Many Days to America? A } \\
\text { Thanksgiving Story by Eve } \\
\text { Bunting and Beth Peck }\end{array}$ & $X$ & $X$ & $X$ & $\mathrm{n} / \mathrm{a}$ \\
\hline $\begin{array}{l}\text { Joseph's Big Ride by Terry } \\
\text { Farish and Ken Daley }\end{array}$ & $\mathrm{n} / \mathrm{a}$ & $\mathrm{n} / \mathrm{a}$ & $\mathrm{n} / \mathrm{a}$ & $X$ \\
\hline $\begin{array}{l}\text { Mali Under the Night Sky: A Lao } \\
\text { Story of Home by Youme } \\
\text { Landowne }\end{array}$ & $X$ & $X$ & $X$ & $X$ \\
\hline $\begin{array}{l}\text { Marwan's Journey by Patricia de } \\
\text { Arias and Laura Borras }\end{array}$ & $X$ & $X$ & $X$ & $X$ \\
\hline $\begin{array}{l}\text { Meltem's Journey: A Refugee } \\
\text { Diary by Anthony Robinson, } \\
\text { Annemarie Young, and June } \\
\text { Allan }\end{array}$ & $X$ & $X$ & $X$ & $X$ \\
\hline $\begin{array}{l}\text { Mohammed's Journey: } A \\
\text { Refugee Diary by Anthony } \\
\text { Robinson, Annemarie Young, } \\
\text { and June Allan }\end{array}$ & $X$ & $X$ & $X$ & $\mathrm{n} / \mathrm{a}$ \\
\hline $\begin{array}{l}\text { My Beautiful Birds by Suzanne } \\
\text { Del Rizzo }\end{array}$ & $X$ & $X$ & $X$ & $X$ \\
\hline $\begin{array}{l}\text { My Freedom Trip: A Child's } \\
\text { Escape from North Korea by } \\
\text { Frances Park, Ginger Park, and } \\
\text { Debra Reid Jenkins }\end{array}$ & $X$ & $X$ & $X$ & $n / a$ \\
\hline $\begin{array}{l}\text { My Name is not Refugee by Kate } \\
\text { Milner }\end{array}$ & $X$ & $\mathrm{n} / \mathrm{a}$ & $X$ & $X$ \\
\hline $\begin{array}{l}\text { My Name is Sangoe/ by Karen } \\
\text { Lynn Williams, Khadra } \\
\text { Mohammed, and Catherine } \\
\text { Stock }\end{array}$ & $X$ & $X$ & $X$ & $X$ \\
\hline $\begin{array}{l}\text { My Two Blankets by Irena Kobald } \\
\text { and Freya Blackwood }\end{array}$ & $X$ & $X$ & n/a & $X$ \\
\hline $\begin{array}{l}\text { Navid's Story by Andy Glynne } \\
\text { and Jonathan Topf }\end{array}$ & $X$ & $X$ & $X$ & $\mathrm{n} / \mathrm{a}$ \\
\hline $\begin{array}{l}\text { Petar's Song by Pratima Mitchell } \\
\text { and Caroline Binch }\end{array}$ & $X$ & $X$ & $X$ & $X$ \\
\hline $\begin{array}{l}\text { Playing War by Kathy Beckwith } \\
\text { and Lea Lyon }\end{array}$ & $X$ & $X$ & $X$ & $X$ \\
\hline $\begin{array}{l}\text { Rachel's Story by Andy Glynne } \\
\text { and Salvador Maldonado }\end{array}$ & $X$ & $X$ & $X$ & $\mathrm{n} / \mathrm{a}$ \\
\hline $\begin{array}{l}\text { Stepping Stones: A Refugee } \\
\text { Family's Journey by Margriet } \\
\text { Ruurs and Nizar Ali Badr }\end{array}$ & $X$ & $X$ & $X$ & $X$ \\
\hline $\begin{array}{l}\text { Teacup by Rebecca Young and } \\
\text { Matt Ottley }\end{array}$ & $X$ & $\mathrm{n} / \mathrm{a}$ & $\mathrm{n} / \mathrm{a}$ & $X$ \\
\hline
\end{tabular}




\begin{tabular}{|c|c|c|c|c|}
\hline $\begin{array}{l}\text { The Banana Leaf Ball: How Play } \\
\text { can Change the World by Katie } \\
\text { Smith Milway and Shane W. } \\
\text { Evans }\end{array}$ & $\mathrm{X}$ & $\mathrm{X}$ & $\mathrm{X}$ & $\mathrm{X}$ \\
\hline $\begin{array}{l}\text { The Boy and the Wall by Youths } \\
\text { at the Lajee Centre in Aida } \\
\text { Refugee Camp, Amahl Bishara, } \\
\text { Linda al-Azzeh, Mohamed } \\
\text { Qassim, Abeer Malash, } \\
\text { Mohamed Sarhaan, Layan al- } \\
\text { Azzeh, Khalid Qarqi, Douha } \\
\text { Musallam, Omar Khador, Hamza } \\
\text { Musallam, and Basil Zubun }\end{array}$ & $\mathrm{n} / \mathrm{a}$ & $\mathrm{X}$ & $\mathrm{X}$ & $\mathrm{X}$ \\
\hline $\begin{array}{l}\text { The Cambodian Dancer by Daryn } \\
\text { Reicherter and Christy Hale }\end{array}$ & $\mathrm{X}$ & $\mathrm{X}$ & $\mathrm{X}$ & $\mathrm{X}$ \\
\hline $\begin{array}{l}\text { The Colour of Home by Mary } \\
\text { Hoffman and Karin Littlewood }\end{array}$ & $\mathrm{X}$ & $\mathrm{X}$ & $\mathrm{X}$ & $\mathrm{X}$ \\
\hline $\begin{array}{l}\text { The Journey by Francesca } \\
\text { Sanna }\end{array}$ & $\mathrm{X}$ & $\mathrm{X}$ & $\mathrm{X}$ & $\mathrm{X}$ \\
\hline $\begin{array}{l}\text { The Little Refugee by Anh Do, } \\
\text { Suzanne Do, and Bruce Whatley }\end{array}$ & $X$ & $\mathrm{X}$ & $X$ & $\mathrm{X}$ \\
\hline The Long Road by Luis Garay & $\mathrm{X}$ & $\mathrm{X}$ & $\mathrm{X}$ & $\mathrm{X}$ \\
\hline $\begin{array}{l}\text { The Roses in My Carpets by } \\
\text { Rukhsana Khan and Ronald } \\
\text { Himler }\end{array}$ & $X$ & $X$ & $X$ & $X$ \\
\hline $\begin{array}{l}\text { The Silence in the Mountains by } \\
\text { Liz Rosenberg and Chris K. } \\
\text { Soentpiet }\end{array}$ & $\mathrm{X}$ & $\mathrm{X}$ & $\mathrm{X}$ & $\mathrm{X}$ \\
\hline $\begin{array}{l}\text { The Silver Path by Christine } \\
\text { Harris and Helen Ong }\end{array}$ & $\mathrm{X}$ & $\mathrm{X}$ & $\mathrm{X}$ & $\mathrm{X}$ \\
\hline $\begin{array}{l}\text { The Treasure Box by Margaret } \\
\text { Wild and Freya Blackwood }\end{array}$ & $\mathrm{X}$ & $\mathrm{X}$ & $\mathrm{X}$ & $\mathrm{X}$ \\
\hline $\begin{array}{l}\text { When I Get Older by K'NAAN, } \\
\text { Sol Guy, and Ruby Gutierrez }\end{array}$ & $\mathrm{X}$ & $\mathrm{X}$ & $X$ & $X$ \\
\hline $\begin{array}{l}\text { Who Belongs Here? An } \\
\text { American Story by Mary Burns } \\
\text { Knight and Anne Sibley O'Brien }\end{array}$ & $\mathrm{X}$ & $\mathrm{X}$ & $\mathrm{X}$ & $\mathrm{n} / \mathrm{a}$ \\
\hline $\begin{array}{l}\text { Ziba Came on a Boat by Liz } \\
\text { Lofthouse and Robert Ingpen }\end{array}$ & $\mathrm{X}$ & $\mathrm{X}$ & $\mathrm{X}$ & $\mathrm{X}$ \\
\hline
\end{tabular}

\section{Author Contact}

Ekaterina Strekalova-Hughes: strekalovahughese@umsystem.edu

Division of Teacher Education and Curriculum Studies, Teacher Education and Curriculum Studies, University of Missouri-Kansas City, 615 E. 52nd Street, Kansas City, Missouri 64110 